\title{
Alike but different: the evolution of the Tubifex tubifex species complex (Annelida, Clitellata) through polyploidization
}

\author{
Roberto Marotta ${ }^{1 *+}$, Angelica Crottini ${ }^{2 \dagger}$, Elena Raimondi ${ }^{3}$, Cristina Fondello ${ }^{4}$ and Marco Ferraguti ${ }^{4}$
}

\begin{abstract}
Background: Tubifex tubifex is a widespread annelid characterized by considerable variability in its taxonomic characteristics and by a mixed reproductive strategy, with both parthenogenesis and biparental reproduction. In a molecular phylogenetic analysis, we detected substantial genetic variability among sympatric Tubifex spp. from the Lambro River (Milano, Italy), which we suggested comprise several cryptic species. To gain insights into the evolutionary events that generated this differentiation, we performed a cytogenetic analysis in parallel with a molecular assay. Approximately 80 cocoons of T. tubifex and T. blanchardi were collected and dissected. For each cocoon, we sequenced a fragment of the 16S rRNA from half of the sibling embryos and karyotyped the other half. To generate a robust phylogeny enabling the reconstruction of the evolutionary processes shaping the diversity of these sympatric lineages, we complemented our original 16S rRNA gene sequences with additional COI sequences.

Results: The chromosome number distribution was consistent with the presence of at least six sympatric euploid chromosome complements (one diploid, one triploid, three tetraploids and one hexaploid), as confirmed by a FISH assay performed with an homologous $18 \mathrm{~S}$ rDNA probe. All the worms with $2 n=50$ chromosomes belonged to an already identified sibling species of T. tubifex, T. blanchardi. The six euploid sets were coherently arranged in the phylogeny, with each lineage grouping specimens with the same chromosome complement.
\end{abstract}

Conclusions: These results are compatible with the hypothesis that multiple polyploidization events, possibly enhanced by parthenogenesis, may have driven the evolution of the T. tubifex species complex.

Keywords: Tubifex, Polyploidy, Speciation, Cryptic species, Reproduction, Cytogenetics, Molecular phylogenetics

\section{Background}

Polyploidy is an important evolutionary mechanism in several taxa, both as a remote mechanism involving ancient genome duplications followed by extensive genetic reshufflings [1] and as a proximal cause of evolution (speciation by polyploidization) as, for example, in flowering plants [2,3] and, to a lesser extent, in animals [4]. Polyploids are often reproductively isolated from their diploid ancestors, as hybrids are anortoploid, producing unbalanced gametes at meiosis [4,5]. Various polyploidization events occurred in the remote past in vertebrates [1], and polyploidy has also been demonstrated among invertebrates, often in combination with parthenogenesis

\footnotetext{
* Correspondence: roberto.marotta@iit.it

${ }^{\dagger}$ Equal contributors

'Istituto Italiano di Tecnologia (IIT), via Morego 30, Genova 16163, Italy

Full list of author information is available at the end of the article
}

or other forms of asexual reproduction [4], thus promoting speciation. Among annelids, polyploidy is widely present in oligochaetous clitellates, with substantial differences within families $[6,7]$.

Tubifex tubifex (Müller, 1774) is a cosmopolitan naidid annelid sensu [8] representing one of the major components of the benthic fauna in freshwater communities [9]. Also present in polluted waters, T. tubifex is widely used in laboratories for ecotoxicology research [10] and as a model organism for the study of annelid development [11]. Tubifex tubifex is characterized by considerable variability in its morphological features [12] and by a mixed reproductive strategy, with parthenogenesis [13], self-fertilization [14], and biparental reproduction through cross-mating [15]. In a molecular phylogenetic analysis of several T. tubifex and T. blanchardi specimens from the Lambro River (an intensively studied site 
in Northern Italy) based on a fragment of the $16 \mathrm{~S}$ rRNA mitochondrial gene, we characterized T. blanchardi, traditionally considered a T. tubifex "morphotype" [9], and confirmed its status as a distinct species by an indepth molecular and morphological analysis [16,17]. Moreover we detected considerable genetic variability among the "T. tubifex" specimens analyzed, and we suggest that these specimens may represent at least two cryptic species [16]. This study is in continuity with our previous work; thus, here, we use the same clade and lineage attributions.

There are no cytogenetic data for $T$. blanchardi and few scattered records of T. tubifex due to the small size and large number of their chromosomes. The available cytogenetic data suggest that the observed morphological and molecular heterogeneity of T. tubifex is mirrored by numerous karyotypic differences [6]. Indeed, the different chromosome numbers proposed for $T$. tubifex $(2 \mathrm{n}=48,2 \mathrm{n}=75,2 \mathrm{n}=100,2 \mathrm{n}=110 ; 2 \mathrm{n}=125$; $2 \mathrm{n}=150)$ might reflect different levels of ploidy within populations [6]. In agreement with these data, the presence of tetra- and hexaploid individuals among the $T$. tubifex inhabiting the Lambro River has been postulated [18] based on an analysis of the allozymes phosphoglucose isomerase (PGI) and phosphoglucose mutase (PGM).

The aim of this study was to investigate polyploidy in sympatric Tubifex lineages coupling cytogenetics with molecular phylogenetics, and discuss how multiple polyploidyzation events, possibly enhanced by parthenogenesis, might have shaped the evolution of this species complex.

\section{Results}

Molecular identification and phylogenetic analysis

Seven indels, 122 variable sites (26.99\%), and the empirical base frequencies $\pi \mathrm{A}=0.319, \pi \mathrm{C}=0.214, \pi \mathrm{G}=0.207$, and $\pi \mathrm{T}=0.258$ were identified in the mitochondrial 16S-rRNA gene alignment of the screened T. tubifex and T. blanchardi embryos, among which 16 haplotypes were identified.

Sequences were compared to the known T. tubifex and T. blanchardi haplotypes from the Lambro River (see Table 1). Building on a previously published analysis [16], seven new haplotypes were identified, but none corresponded to a potentially new genetic lineage and/or clade. Some of the material used by [16] has been recently reanalyzed (both molecularly and morphologically), thus allowing for the attribution of two of the haplotypes formerly assigned to the $T$. tubifex species complex (haplotype A11 and A12 in [16]) to another oligochaetous clitellate species, Potamotrix bavaricus ([19]; personal observations).
The four partitioned Bayesian inference runs performed using both 16S rRNA and COI gene fragments (details below) identified 17 nodes, 13 of which were supported by posterior probabilities $\geq 0.99$ in all runs (Figure 1). Tubifex tubifex and T. blanchardi haplotypes were organized in seven lineages. All T. blanchardi had an identical mitochondrial haplotype (Figure 1; Clade 1), while T. tubifex individuals comprised 15 different haplotypes, arranged in two well-supported major clades (Figure 1; Clades 2 and 3). Seven T. tubifex haplotypes (haplotypes: II, III, VI, VII, XIII, XIV, XVI) formed four well-supported lineages (see Figure 1; Lineages 2a-d), together being the sister group of the $T$. blanchardi clade (Figure 1; Clade 1 and Clade 2, 1.00 posterior probability values). Eight other haplotypes (haplotypes: VIII, IX, X, XI, XII, XVII, XVIII, XIX), assembled in two well supported lineages (see Figure 1; Lineages 3a-b), formed Clade 3 (0.99 posterior probability value), a sister group of the Clade1/Clade2 assemblage.

Within and between clades and lineages, the average uncorrected divergences at the $16 \mathrm{~S}$ rRNA gene, summarized in Tables 2 and 3, were similar to those already published in [16]. Clades 2 and 3 showed a within-clade average uncorrected divergence ( $p$-distance, transformed into percent using the complete delete option) of approximately $5 \%$ (see Table 2 ). The genetic distances between T. blanchardi and the other two clades were striking, ranging from $10.2 \%$ to $12.7 \%$; by contrast, the genetic divergence between lineages of the same clade was low (see Table 3). A very low within-lineage genetic divergence $(0.2 \%$ to $1.1 \%)$ characterized the $T$. tubifex lineages (see Table 2).

\section{Cytogenetic analysis}

\section{Chromosome-number distribution}

Based on the analysis of more than 80 metaphase plates, T. blanchardi showed a unimodal distribution, with a modal chromosome number of 50 . The chromosomenumber distribution of the T. tubifex, based on the analysis of more than 290 metaphase plates, showed a trimodal pattern, with a primary mode of 100 chromosomes and secondary and tertiary modes of 75 and 150 chromosomes, respectively (Figure 2).

\section{Karyotype reconstruction}

The GIEMSA-stained metaphase plates of T. blanchardi and T. tubifex were selected on the basis of spreading quality to minimize the number of artifacts due to loss or gain of single chromosomes. The chromosomes were aligned by decreasing size; on the basis of centromere position, they were classified as meta and submetacentric chromosomes or acrocentric chromosomes. It was not possible to reconstruct the karyotype of the rare $T$. tubifex lineage $2 \mathrm{~d}$ due to the poor quality of the few metaphases observed. The size and relative number of 
Table 1 Samples analyzed

\begin{tabular}{|c|c|c|c|c|c|c|c|c|c|}
\hline Sample & Taxon & $\begin{array}{c}N^{\circ} \text { embryos for } \\
\text { sequencing }\end{array}$ & $\begin{array}{c}N^{\circ} \text { embryos for } \\
\text { cytogenetics }\end{array}$ & Haplotype & Clade & Lineage & $\begin{array}{c}\text { Chromosome } \\
\text { number }\end{array}$ & GenBank & Locality \\
\hline TAC138 & $\begin{array}{c}\text { Tubifex } \\
\text { blanchardi }\end{array}$ & 1 & 1 & - & - & - & 50 & - & $\begin{array}{l}\text { Lambro River, } \\
\text { Italy }\end{array}$ \\
\hline TAC139 & $\begin{array}{c}\text { Tubifex } \\
\text { blanchardi }\end{array}$ & 2 & 1 & - & - & - & 50 & - & $\begin{array}{l}\text { Lambro River, } \\
\text { Italy }\end{array}$ \\
\hline TAC140 & $\begin{array}{c}\text { Tubifex } \\
\text { blanchardi }\end{array}$ & 1 & 2 & 1 & 1 & 1 & 50 & JQ247438 & $\begin{array}{l}\text { Lambro River, } \\
\text { Italy }\end{array}$ \\
\hline TAC141 & Tubifex tubifex & 3 & 2 & $\mathrm{Vl}$ & 2 & $2 a$ & 75 & JQ247439 & $\begin{array}{l}\text { Lambro River, } \\
\text { Italy }\end{array}$ \\
\hline TAC142 & Tubifex tubifex & 3 & 2 & $\mathrm{Vl}$ & 2 & $2 \mathrm{a}$ & 75 & JQ247440 & $\begin{array}{c}\text { Lambro River, } \\
\text { Italy }\end{array}$ \\
\hline TAC143 & Tubifex tubifex & 2 & 1 & $\mathrm{VII}$ & 2 & $2 b$ & 100 & JQ247441 & $\begin{array}{l}\text { Lambro River, } \\
\text { Italy }\end{array}$ \\
\hline TAC144 & Tubifex tubifex & 1 & 2 & - & - & - & 100 & - & $\begin{array}{l}\text { Lambro River, } \\
\text { Italy }\end{array}$ \\
\hline TAC145 & Tubifex tubifex & 2 & 1 & $\mathrm{XVI}$ & 2 & $2 b$ & 100 & JQ247442 & $\begin{array}{l}\text { Lambro River, } \\
\text { Italy }\end{array}$ \\
\hline TAC146 & Tubifex tubifex & 2 & 1 & $\mathrm{VII}$ & 2 & $2 b$ & 100 & JQ247443 & $\begin{array}{l}\text { Lambro River, } \\
\text { Italy }\end{array}$ \\
\hline TAC147 & Tubifex tubifex & 1 & 2 & XIX & 3 & $3 a$ & 100 & JQ247444 & $\begin{array}{l}\text { Lambro River, } \\
\text { Italy }\end{array}$ \\
\hline TAC148 & Tubifex tubifex & 1 & 1 & $X I$ & 3 & $3 a$ & 100 & JQ247445 & $\begin{array}{l}\text { Lambro River, } \\
\text { Italy }\end{array}$ \\
\hline TAC149 & Tubifex tubifex & 2 & 2 & $\mathrm{Vl}$ & 2 & $2 a$ & 75 & JQ247446 & $\begin{array}{l}\text { Lambro River, } \\
\text { Italy }\end{array}$ \\
\hline TAC150 & Tubifex tubifex & 2 & 2 & VII & 2 & $2 b$ & - & JQ247447 & $\begin{array}{l}\text { Lambro River, } \\
\text { Italy }\end{array}$ \\
\hline TAC151 & Tubifex tubifex & 3 & 2 & XIX & 3 & $3 a$ & 100 & JQ247448 & $\begin{array}{l}\text { Lambro River, } \\
\text { Italy }\end{array}$ \\
\hline TAC152 & Tubifex tubifex & 1 & 2 & $X V I I I$ & 3 & $3 b$ & 100 & JQ247449 & $\begin{array}{l}\text { Lambro River, } \\
\text { Italy }\end{array}$ \\
\hline TAC153 & Tubifex tubifex & 2 & 1 & $X V I I I$ & 3 & $3 b$ & 100 & JQ247450 & $\begin{array}{l}\text { Lambro River, } \\
\text { Italy }\end{array}$ \\
\hline TAC154 & Tubifex tubifex & 2 & 2 & - & - & - & 100 & - & $\begin{array}{l}\text { Lambro River, } \\
\text { Italy }\end{array}$ \\
\hline TAC155 & Tubifex tubifex & 2 & 1 & VII & 2 & $2 b$ & 100 & JQ247451 & $\begin{array}{l}\text { Lambro River, } \\
\text { Italy }\end{array}$ \\
\hline TAC156 & Tubifex tubifex & 1 & 1 & $\mathrm{XVIII}$ & 3 & $3 b$ & 100 & JQ247452 & $\begin{array}{l}\text { Lambro River, } \\
\text { Italy }\end{array}$ \\
\hline TAC157 & Tubifex tubifex & 2 & 1 & VII & 2 & $2 b$ & 100 & JQ247453 & $\begin{array}{l}\text { Lambro River, } \\
\text { Italy }\end{array}$ \\
\hline TAC158 & Tubifex tubifex & 2 & 1 & $X \mathrm{VIII}$ & 3 & $3 b$ & 100 & JQ247454 & $\begin{array}{l}\text { Lambro River, } \\
\text { Italy }\end{array}$ \\
\hline TAC159 & Tubifex tubifex & 2 & 2 & VII & 2 & $2 b$ & 100 & JQ247455 & $\begin{array}{l}\text { Lambro River, } \\
\text { Italy }\end{array}$ \\
\hline TAC160 & Tubifex tubifex & 2 & 1 & $X \mathrm{X} I I I$ & 3 & $3 b$ & 100 & JQ247456 & $\begin{array}{l}\text { Lambro River, } \\
\text { Italy }\end{array}$ \\
\hline TAC161 & Tubifex tubifex & 5 & 2 & XIV & 2 & $2 c$ & 150 & JQ247457 & $\begin{array}{l}\text { Lambro River, } \\
\text { Italy }\end{array}$ \\
\hline TAC162 & Tubifex tubifex & 4 & 3 & XIV & 2 & $2 c$ & 150 & JQ247458 & $\begin{array}{l}\text { Lambro River, } \\
\text { Italy }\end{array}$ \\
\hline TAC163 & Tubifex tubifex & 1 & 1 & XIX & 3 & $3 a$ & 100 & JQ247459 & $\begin{array}{l}\text { Lambro River, } \\
\text { Italy }\end{array}$ \\
\hline
\end{tabular}


Table 1 Samples analyzed (Continued)

\begin{tabular}{|c|c|c|c|c|c|c|c|c|c|}
\hline TAC164 & Tubifex tubifex & 3 & 1 & $\mathrm{VII}$ & 2 & $2 b$ & 100 & JQ247460 & $\begin{array}{l}\text { Lambro River, } \\
\text { Italy }\end{array}$ \\
\hline TAC165 & Tubifex tubifex & 3 & 1 & XIV & 2 & $2 c$ & 150 & JQ247461 & $\begin{array}{l}\text { Lambro River, } \\
\text { Italy }\end{array}$ \\
\hline TAC166 & Tubifex tubifex & 2 & 2 & XIV & 2 & $2 c$ & - & JQ247462 & $\begin{array}{l}\text { Lambro River, } \\
\text { Italy }\end{array}$ \\
\hline TAC168 & Tubifex tubifex & 1 & 1 & $X \mathrm{VI}$ & 2 & $2 b$ & 100 & JQ247463 & $\begin{array}{l}\text { Lambro River, } \\
\text { Italy }\end{array}$ \\
\hline TAC169 & Tubifex tubifex & 5 & 2 & XIV & 2 & $2 c$ & 150 & JQ247464 & $\begin{array}{l}\text { Lambro River, } \\
\text { Italy }\end{array}$ \\
\hline TAC170 & Tubifex tubifex & 2 & 1 & VII & 2 & $2 b$ & 100 & JQ247465 & $\begin{array}{l}\text { Lambro River, } \\
\text { Italy }\end{array}$ \\
\hline TAC171 & Tubifex tubifex & 2 & 2 & $X V I I$ & 3 & $3 b$ & 100 & JQ247466 & $\begin{array}{l}\text { Lambro River, } \\
\text { Italy }\end{array}$ \\
\hline TAC172 & Tubifex tubifex & 3 & 2 & XIV & 2 & $2 c$ & 150 & JQ247467 & $\begin{array}{l}\text { Lambro River, } \\
\text { Italy }\end{array}$ \\
\hline TAC173 & Tubifex tubifex & 2 & 1 & XII & 3 & $3 a$ & 100 & JQ247468 & $\begin{array}{l}\text { Lambro River, } \\
\text { Italy }\end{array}$ \\
\hline TAC174 & Tubifex tubifex & 2 & 2 & - & - & - & 75 & - & $\begin{array}{l}\text { Lambro River, } \\
\text { Italy }\end{array}$ \\
\hline TAC175 & Tubifex tubifex & 2 & 1 & VII & 2 & $2 b$ & 100 & JQ247469 & $\begin{array}{l}\text { Lambro River, } \\
\text { Italy }\end{array}$ \\
\hline TAC176 & Tubifex tubifex & 2 & 1 & XIV & 2 & $2 c$ & 150 & JQ247470 & $\begin{array}{l}\text { Lambro River, } \\
\text { Italy }\end{array}$ \\
\hline TAC177 & Tubifex tubifex & 1 & 1 & VII & 2 & $2 b$ & 100 & JQ247471 & $\begin{array}{l}\text { Lambro River, } \\
\text { Italy }\end{array}$ \\
\hline TAC178 & Tubifex tubifex & 2 & 2 & $x$ & 3 & $3 a$ & 100 & JQ247472 & $\begin{array}{l}\text { Lambro River, } \\
\text { Italy }\end{array}$ \\
\hline TAC179 & Tubifex tubifex & 7 & 3 & XIV & 2 & $2 c$ & 150 & JQ247473 & $\begin{array}{l}\text { Lambro River, } \\
\text { Italy }\end{array}$ \\
\hline TAC180 & $\begin{array}{c}\text { Tubifex } \\
\text { blanchardi }\end{array}$ & 2 & 2 & । & 1 & 1 & - & JQ247474 & $\begin{array}{l}\text { Lambro River, } \\
\text { Italy }\end{array}$ \\
\hline TAC181 & $\begin{array}{c}\text { Tubifex } \\
\text { blanchardi }\end{array}$ & 1 & 1 & । & 1 & 1 & 50 & JQ247475 & $\begin{array}{l}\text { Lambro River, } \\
\text { Italy }\end{array}$ \\
\hline TAC182 & Tubifex tubifex & 1 & 1 & $\mathrm{Vl}$ & 2 & $2 a$ & 75 & JQ247476 & $\begin{array}{l}\text { Lambro River, } \\
\text { Italy }\end{array}$ \\
\hline TAC183 & Tubifex tubifex & 1 & 1 & VII & 2 & $2 b$ & 100 & JQ247477 & $\begin{array}{l}\text { Lambro River, } \\
\text { Italy }\end{array}$ \\
\hline TAC184 & Tubifex tubifex & 2 & 2 & VII & 2 & $2 b$ & 100 & JQ247478 & $\begin{array}{l}\text { Lambro River, } \\
\text { Italy }\end{array}$ \\
\hline TAC185 & Tubifex tubifex & 2 & 1 & VII & 2 & $2 b$ & 100 & JQ247479 & $\begin{array}{l}\text { Lambro River, } \\
\text { Italy }\end{array}$ \\
\hline TAC186 & Tubifex tubifex & 1 & 2 & $\mathrm{Vl}$ & 2 & $2 a$ & 75 & JQ247480 & $\begin{array}{l}\text { Lambro River, } \\
\text { Italy }\end{array}$ \\
\hline TAC187 & Tubifex tubifex & 2 & 1 & $X V I I I$ & 3 & $3 b$ & 100 & JQ247481 & $\begin{array}{l}\text { Lambro River, } \\
\text { Italy }\end{array}$ \\
\hline TAC188 & Tubifex tubifex & 2 & 1 & XIX & 3 & $3 a$ & 100 & JQ247482 & $\begin{array}{l}\text { Lambro River, } \\
\text { Italy }\end{array}$ \\
\hline TAC189 & Tubifex tubifex & 2 & 2 & XII & 3 & $3 a$ & 100 & JQ247483 & $\begin{array}{l}\text { Lambro River, } \\
\text { Italy }\end{array}$ \\
\hline TAC190 & Tubifex tubifex & 2 & 2 & $\mathrm{Vl}$ & 2 & $2 a$ & 75 & JQ247484 & $\begin{array}{l}\text { Lambro River, } \\
\text { Italy }\end{array}$ \\
\hline TAC191 & Tubifex tubifex & 2 & 1 & VII & 2 & $2 b$ & 100 & JQ247485 & $\begin{array}{l}\text { Lambro River, } \\
\text { Italy }\end{array}$ \\
\hline
\end{tabular}


Table 1 Samples analyzed (Continued)

\begin{tabular}{|c|c|c|c|c|c|c|c|c|c|}
\hline TAC192 & Tubifex tubifex & 2 & 1 & $\mathrm{VII}$ & 2 & $2 b$ & 100 & JQ247486 & $\begin{array}{l}\text { Lambro River, } \\
\text { Italy }\end{array}$ \\
\hline TAC193 & Tubifex tubifex & 4 & 2 & XIV & 2 & $2 c$ & 150 & JQ247487 & Estonia \\
\hline TAC194 & Tubifex tubifex & 5 & 2 & XIV & 2 & $2 c$ & 150 & JQ247488 & Estonia \\
\hline TAC195 & $\begin{array}{c}\text { Tubifex } \\
\text { blanchardi }\end{array}$ & 2 & 1 & । & 1 & 1 & 50 & JQ247489 & $\begin{array}{l}\text { Lambro River, } \\
\text { Italy }\end{array}$ \\
\hline TAC196 & $\begin{array}{c}\text { Tubifex } \\
\text { blanchardi }\end{array}$ & 2 & 1 & I & 1 & 1 & - & JQ247490 & $\begin{array}{l}\text { Lambro River, } \\
\text { Italy }\end{array}$ \\
\hline TAC197 & Tubifex tubifex & 4 & 4 & $\mathrm{Vl}$ & 2 & $2 a$ & 75 & JQ247491 & $\begin{array}{l}\text { Lambro River, } \\
\text { Italy }\end{array}$ \\
\hline TAC198 & Tubifex tubifex & 2 & 2 & $\mathrm{Vl}$ & 2 & $2 a$ & 75 & JQ247492 & $\begin{array}{l}\text { Lambro River, } \\
\text { Italy }\end{array}$ \\
\hline TAC199 & Tubifex tubifex & 1 & 1 & VII & 2 & $2 b$ & 100 & JQ247493 & $\begin{array}{l}\text { Lambro River, } \\
\text { Italy }\end{array}$ \\
\hline TAC200 & Tubifex tubifex & 1 & 1 & $X V I I I$ & 3 & $3 b$ & 100 & JQ247494 & $\begin{array}{l}\text { Lambro River, } \\
\text { Italy }\end{array}$ \\
\hline TAC201 & Tubifex tubifex & 1 & 1 & $X V I I I$ & 3 & $3 b$ & 100 & JQ247495 & $\begin{array}{l}\text { Lambro River, } \\
\text { Italy }\end{array}$ \\
\hline TAC202 & $\begin{array}{c}\text { Tubifex } \\
\text { blanchardi }\end{array}$ & 3 & 2 & I & 1 & 1 & 50 & JQ247496 & $\begin{array}{l}\text { Lambro River, } \\
\text { Italy }\end{array}$ \\
\hline TAC203 & $\begin{array}{c}\text { Tubifex } \\
\text { blanchardi }\end{array}$ & 2 & 1 & । & 1 & 1 & 50 & JQ247497 & $\begin{array}{l}\text { Lambro River, } \\
\text { Italy }\end{array}$ \\
\hline TAC204 & $\begin{array}{c}\text { Tubifex } \\
\text { blanchardi }\end{array}$ & 2 & 1 & । & 1 & 1 & - & JQ247498 & $\begin{array}{l}\text { Lambro River, } \\
\text { Italy }\end{array}$ \\
\hline TAC205 & Tubifex tubifex & 1 & 1 & XIX & 3 & $3 a$ & - & JQ247499 & $\begin{array}{l}\text { Lambro River, } \\
\text { Italy }\end{array}$ \\
\hline TAC206 & Tubifex tubifex & 2 & 2 & $\mathrm{Vl}$ & 2 & $2 a$ & - & JQ247500 & $\begin{array}{l}\text { Lambro River, } \\
\text { Italy }\end{array}$ \\
\hline TAC207 & Tubifex tubifex & 3 & 2 & $\mathrm{VI}$ & 2 & $2 a$ & 75 & $J Q 247501$ & $\begin{array}{l}\text { Lambro River, } \\
\text { Italy }\end{array}$ \\
\hline TAC208 & Tubifex tubifex & 3 & 2 & $\mathrm{VI}$ & 2 & $2 a$ & 75 & JQ247502 & $\begin{array}{l}\text { Lambro River, } \\
\text { Italy }\end{array}$ \\
\hline TAC209 & Tubifex tubifex & 3 & 2 & $\mathrm{Vl}$ & 2 & $2 a$ & 75 & JQ247503 & $\begin{array}{l}\text { Lambro River, } \\
\text { Italy }\end{array}$ \\
\hline TAC210 & Tubifex tubifex & 1 & 2 & $\mathrm{Vl}$ & 2 & $2 a$ & - & JQ247504 & $\begin{array}{l}\text { Lambro River, } \\
\text { Italy }\end{array}$ \\
\hline TAC211 & Tubifex tubifex & 3 & 2 & $\mathrm{Vl}$ & 2 & $2 a$ & - & JQ247505 & $\begin{array}{l}\text { Lambro River, } \\
\text { Italy }\end{array}$ \\
\hline TAC212 & Tubifex tubifex & 4 & 4 & $\mathrm{VI}$ & 2 & $2 a$ & 75 & JQ247506 & $\begin{array}{l}\text { Lambro River, } \\
\text { Italy }\end{array}$ \\
\hline TAC213 & Tubifex tubifex & 3 & 3 & XIV & 2 & $2 c$ & 150 & JQ247507 & Estonia \\
\hline TAC214 & Tubifex tubifex & 5 & 4 & XIV & 2 & $2 c$ & 150 & JQ247508 & Estonia \\
\hline TAC215 & Tubifex tubifex & 2 & 2 & XIV & 2 & $2 c$ & 150 & JQ247509 & Estonia \\
\hline TAC216 & Tubifex tubifex & 4 & 2 & XIV & 2 & $2 c$ & 150 & JQ247510 & Estonia \\
\hline TAC217 & Tubifex tubifex & 5 & 3 & XIV & 2 & $2 c$ & - & JQ247511 & Estonia \\
\hline $27-\mathrm{T}$ & Tubifex tubifex & 3 & 4 & $\|$ & 2 & $2 d$ & 100 & JQ247437 & $\begin{array}{l}\text { Lambro River, } \\
\text { Italy }\end{array}$ \\
\hline
\end{tabular}

Haplotypes, clades and lineage attributions were as in [16].

List of samples (31 embryos from 10 cocoons of T. blanchardi and 140 embryos from 70 cocoons of T. tubifex) used in parallel for cytogenetic and molecular analyses, with reference to the taxon and the number of embryos used for 16S rRNA gene sequencing and metaphase preparation, 16S rRNA gene haplotype, clade and lineage attribution and number of chromosomes. GenBank accession numbers and locality are also provided. 
Table 2 Within clade (bold) and within lineage genetic divergence of the analysed 16S rRNA gene fragment

\begin{tabular}{lc}
\hline T. blanchardi_1 & $\mathbf{n} / \mathbf{c}$ \\
\hline T. tubifex_2 & $\mathbf{5 . 4 \%}$ \\
T. tubifex_2a & $\mathrm{n} / \mathrm{c}$ \\
T. tubifex_2b & $0.7 \%$ \\
T. tubifex_2C & $0.2 \%$ \\
T. tubifex_2d & $1.1 \%$ \\
T. tubifex_3 & $\mathbf{5 . 0 \%}$ \\
T. tubifex_3a & $0.6 \%$ \\
T. tubifex_3b & $1.0 \%$ \\
\hline
\end{tabular}

The genetic divergence is based on the pairwise distance calculation (using the complete delete option) for the $T$. blanchardi and the different $T$. tubifex clades and lineages. meta- submeta- and acrocentric chromosomes for the representative karyotypes of the various lineages are summarized in Figure 3. One, two and four metacentric chromosomes significantly larger than the others were found in the metaphase plates of lineages $2 b$ (one), $2 \mathrm{c}$ (two), 3a and 3b (four; Figures 1 and 3).

\section{In-Situ Hybridization}

Due to the large number and small size of the T. tubifex and T. blanchardi chromosomes, it was impossible to finely localize the $18 \mathrm{~S}$ rDNA signals on specific chromosomes; we therefore simply counted the number of hybridization signals in each metaphase plate. All the analyzed metaphase plates from T. blanchardi showed two hybridization signals (Figure 4A), while $T$. tubifex lineage 2a (75 chromosomes) showed three 
Table 3 Among clades (bold) and among lineages genetic divergence of the analysed 16S rRNA gene fragment

\begin{tabular}{|c|c|c|c|c|c|c|c|c|c|}
\hline & T. blanchardi_1 & T. tubifex_2 & T. tubifex_2a & T. tubifex_2b & T. tubifex_2c & T. tubifex_2d & T. tubifex_3 & T. tubifex_3a & T. tubifex_3b \\
\hline T. blanchardi_1 & - & - & & & & & & & \\
\hline T. tubifex_2 & $10.2 \%$ & - & & & & & & & \\
\hline T. tubifex_2a & $10.1 \%$ & - & - & & & & & & \\
\hline T. tubifex_2b & $9.8 \%$ & - & $7.3 \%$ & - & & & & & \\
\hline T. tubifex_2C & $11.3 \%$ & - & $6.2 \%$ & $7.3 \%$ & - & & & & \\
\hline T. tubifex_2d & $9.6 \%$ & - & $6.7 \%$ & $5.6 \%$ & $5.0 \%$ & - & & & \\
\hline T. tubifex_3 & $12.7 \%$ & $12.7 \%$ & - & - & - & - & - & & \\
\hline T. tubifex_3a & $12.6 \%$ & - & $12.5 \%$ & $12.5 \%$ & $13.7 \%$ & $13.0 \%$ & - & - & \\
\hline T. tubifex_3b & $12.7 \%$ & - & $11.4 \%$ & $12.8 \%$ & $13.0 \%$ & $12.1 \%$ & - & $8.1 \%$ & - \\
\hline
\end{tabular}

The genetic divergence is based on the pairwise distance calculation (using the complete delete option) for the $T$. blanchardi and the different $T$. tubifex clades and lineages.

hybridization signals (Figure 4B); lineages 2b, 2d, 3a and $3 \mathrm{~b}$ (100 chromosomes), showed four hybridization signals (Figure 4C); and lineage 2c (150 chromosomes) showed six hybridization signals (Figure 4D).

\section{Discussion}

The karyotype of Tubifex blanchardi, assessed here for the first time, differed from that of the other sympatric T. tubifex lineages, thus corroborating its status as a distinct species, as proposed by [16]. The observed chromosome numbers and size distribution were consistent with the presence of at least six sympatric euploid chromosome complements, corresponding to one diploid ( $\mathrm{n}=50, T$. blanchardi), one triploid $(\mathrm{n}=75)$, three tetraploids $(\mathrm{n}=100)$ and one hexaploid $(\mathrm{n}=150)$ T. tubifex populations. All 7 analyzed T. tubifex from Estonia were hexaploid $(2 \mathrm{n}=150)$ and grouped into lineage $2 \mathrm{c}$, with other individuals from the Lambro River. The

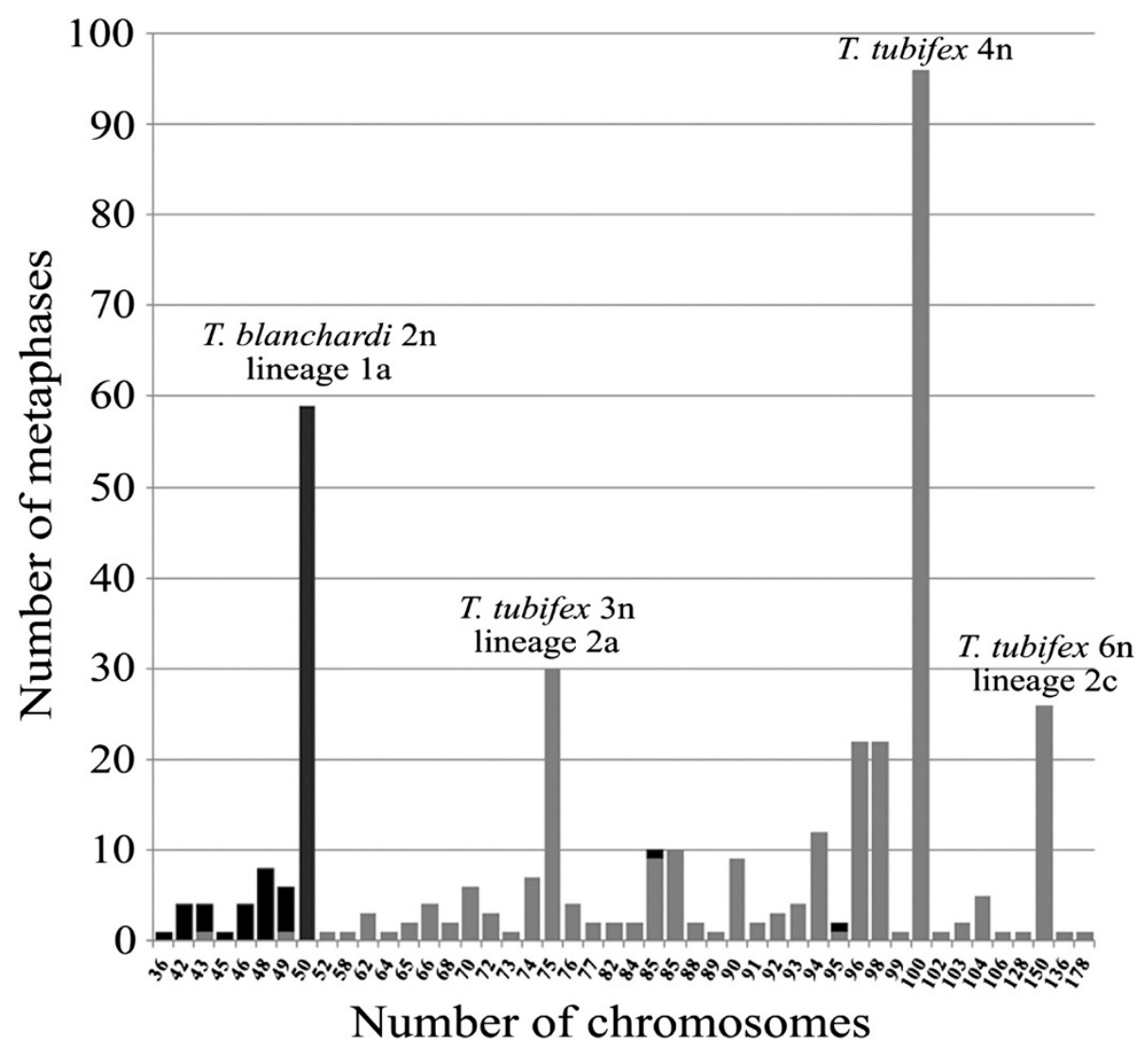

Figure 2 Chromosome-number distribution. Histogram showing the chromosome-number distribution in Tubifex blanchardi (black) and T. tubifex (gray). 


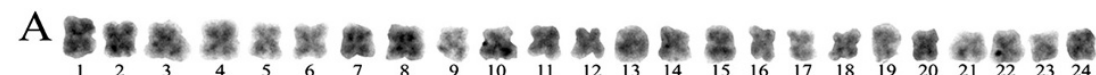

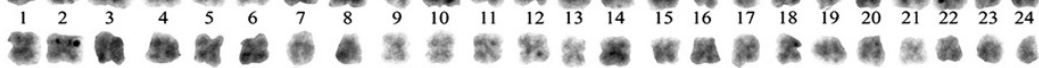
$\begin{array}{llllllllllllllllllllllll}25 & 26 & \underline{27} & \underline{28} & 29 & 30 & \underline{31} & \underline{32} & 33 & 34 & 35 & 36 & 37 & 38 & 39 & 40 & 41 & 42 & \underline{43} & \underline{44} & 45 & 46 & \underline{47} & \underline{48}\end{array}$ $49 \quad 50$

$\mathrm{B}$ * 4 ถ $\begin{array}{llllllllllllllllllllllll}1 & 2 & 3 & 4 & 5 & 6 & 7 & 8 & 9 & 10 & 11 & 12 & 13 & 14 & 15 & 16 & 17 & 18 & 19 & 20 & 21 & 22 & 23 & 24\end{array}$

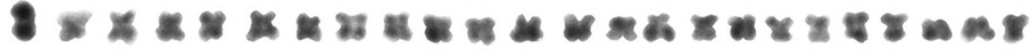
$\begin{array}{llllllllllllllllllllllll}25 & 26 & 27 & 28 & 29 & 30 & 31 & 32 & 33 & 34 & 35 & 36 & 37 & 38 & 39 & 40 & 41 & 42 & 43 & 44 & 45 & 46 & 47 & 48\end{array}$

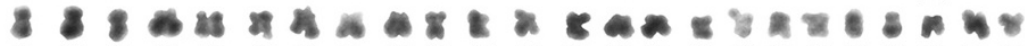
$\begin{array}{llllllllllllllllllllllll}49 & 50 & 51 & \underline{52} & \underline{53} & \underline{54} & \underline{55} & \underline{56} & \underline{57} & 58 & 59 & 60 & 61 & \underline{62} & \underline{63} & 64 & 65 & 66 & 67 & 68 & 69 & \underline{70} & 71 & 72\end{array}$

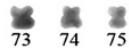

C 울 7.

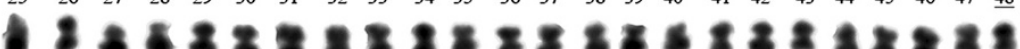
$\begin{array}{llllllllllllllllllllllll}49 & 50 & 51 & 52 & 53 & 54 & 55 & 56 & 57 & 58 & 59 & 60 & 61 & 62 & 63 & 64 & 65 & 66 & 67 & 68 & 69 & 70 & 71 & 72\end{array}$

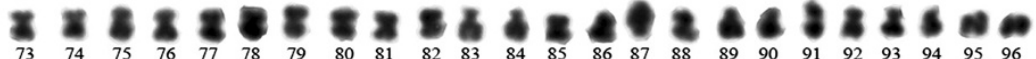
$\rightarrow \mathbf{0}$

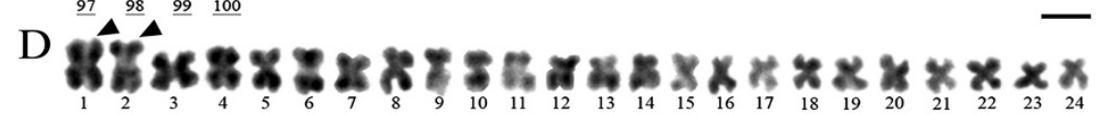

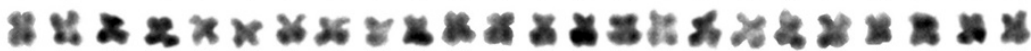
$\begin{array}{lllllllllllllllllllllllll}25 & 26 & 27 & 28 & 29 & 30 & 31 & 32 & 33 & 34 & 35 & 36 & 37 & 38 & 39 & 40 & 41 & 42 & 43 & 44 & 45 & 46 & 47 & 48\end{array}$

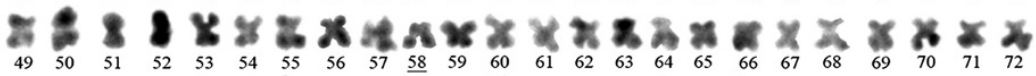

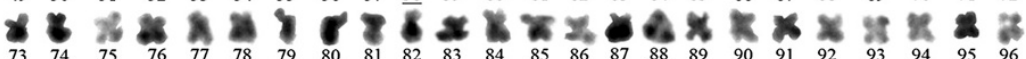

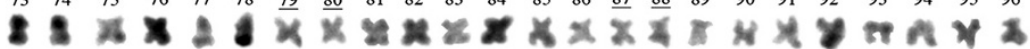
$\begin{array}{llllllllllllllllllllllll}97 & 98 & 99 & 100 & 101 & 102 & 103 & 104 & 105 & 106 & 107 & 108 & 109 & 110 & 111 & 112 & 113 & 114 & 115 & 116 & 117 & 118 & 119 & 120\end{array}$

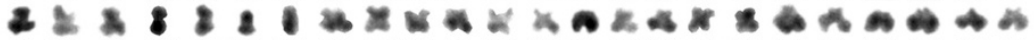

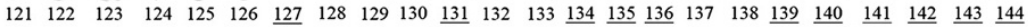
B 4 a $A$ $145 \quad 146 \quad 147 \quad 148 \quad 149 \frac{150}{10}$

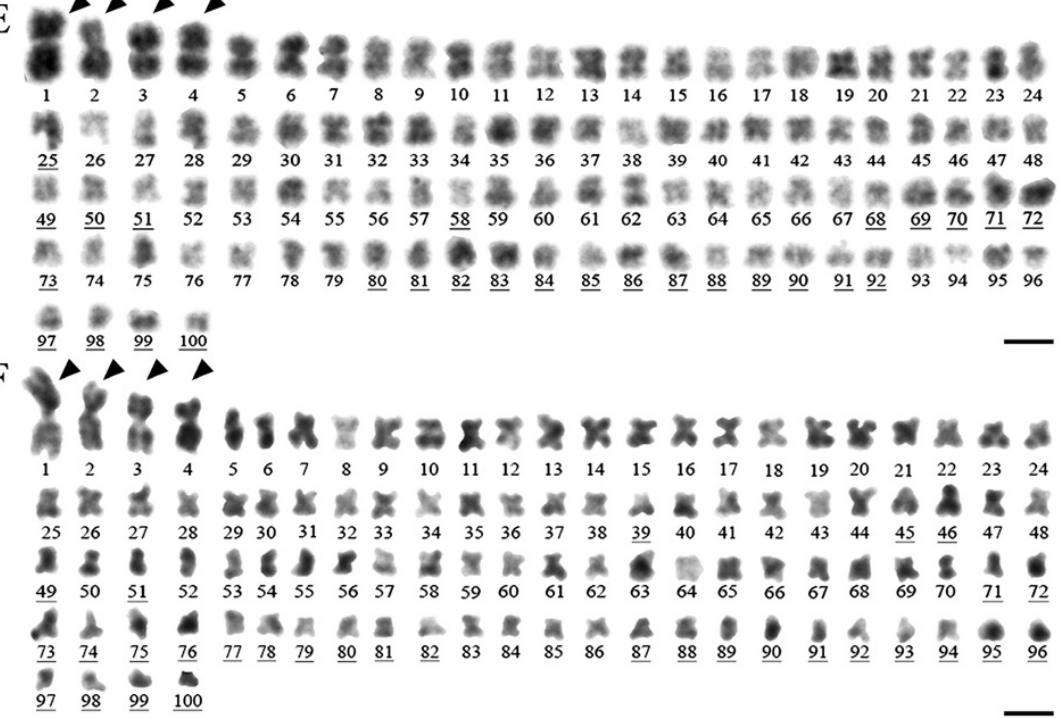

Figure $\mathbf{3}$ (See legend on next page.) 
(See figure on previous page.)

Figure 3 Karyotype reconstruction on metaphase chromosomes of $T$. blanchardi and of the $T$. tubifex lineages of the Lambro River. A. The diploid T. blanchardi $(2 n=50)$, consisting of 42 meta- and submetacentric chromosomes and 8 acrocentric chromosomes; $\mathbf{B}$. the triploid Tubifex (lineage $2 \mathrm{a}, 3 \mathrm{n}=75$ ) composed of 64 meta submetacentric chromosomes and 11 acrocentric chromosomes; $\mathbf{C}$. the tetraploid Tubifex (lineage $2 \mathrm{~b}, 4 \mathrm{n}=100$ ) composed of 87 meta-, submetacentric chromosomes and 13 acrocentric chromosomes, with one large metacentric chromosome marker (arrowhead); D. the hexaploid Tubifex (lineage 2c, $6 n=150$ ), composed of 128 meta- submetacentric chromosomes and 22 acrocentric chromosomes, with two large metacentric chromosome markers (arrowheads); $\mathbf{E}$. the tetraploid Tubifex (lineages 3a, 2n=100) composed of 74 meta- or submetacentric and 26 acrocentric chromosomes, with four large metacentric chromosome markers (arrowheads); F. the tetraploid Tubifex (lineages 3b, $2 n=100$ ) composed of 69 meta- or submetacentric chromosomes and 31 acrocentric chromosomes, with four large metacentric chromosome markers (arrowheads). Numbers indicate the meta- or submetacentric chromosomes; underlined numbers indicate acrocentric chromosomes. Scale bars are $4 \mu \mathrm{m}$ in $\mathrm{A}, 3 \mu \mathrm{m}$ in $\mathrm{B}, 2.5 \mu \mathrm{m}$ in D and $2 \mu \mathrm{m}$ in $\mathrm{C}$, E, and F.

numbers of hybridization signals we observed in T. blanchardi and in the various T. tubifex lineages were consistent with the ploidy levels inferred from the analysis of the chromosome number distribution. The presence of large metacentric chromosomes proportionate in number to the ploidy level, as proposed by [6], has been verified only for the tetraploid $T$. tubifex belonging to Clade 3, which have four large metacentric chromosomes. Only one large metacentric chromosome was observed in the tetraploid lineage $2 \mathrm{~b}$, and two large metacentric chromosomes were observed in the hexaploid lineage 2c (see Figure 1). The large metacentric chromosomes might be derived from centric fusions of acrocentric chromosomes (Robertsonian translocation), as already reported in other families of oligochaetous clitellates (for example, among enchytraeids and lumbricids; [6]). By mapping the $T$.

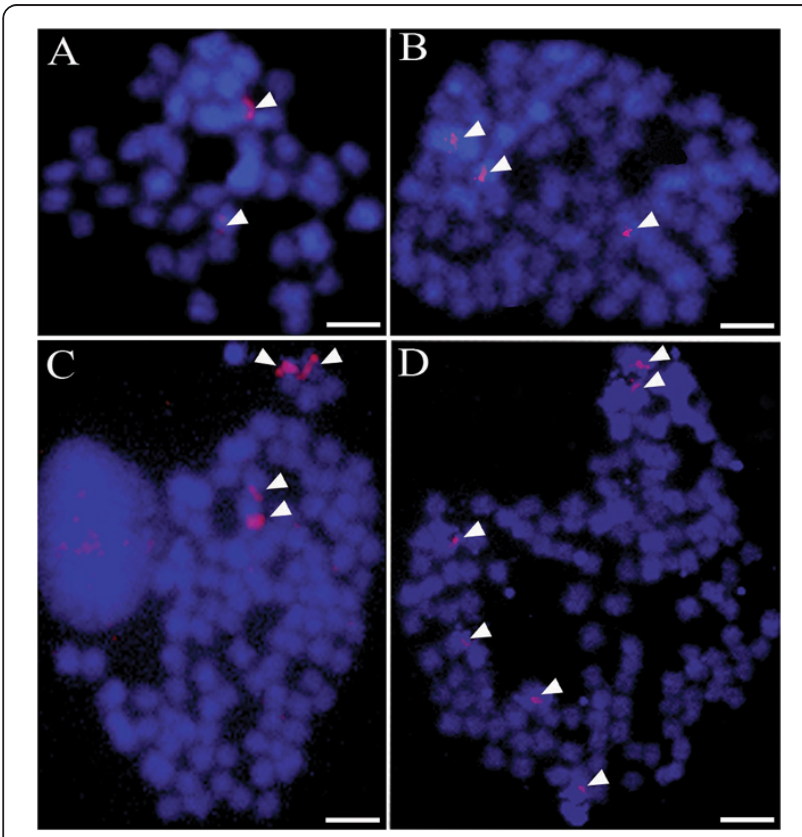

Figure 4 FISH analysis of metaphase chromosomes of $T$. blanchardi (A) and the Tubifex lineages of the Lambro River with 75 (B), 100 (C) and 150 (D) chromosomes. The chromosomes are pseudocolored in blue, and the 18S rRNA gene hybridization signals are pseudocolored in red (arrowheads). Scale bars are $4 \mu \mathrm{m}$. tubifex and T. blanchardi karyotypes on the phylogenetic tree, we identified at least two T. tubifex clades: the two tetraploid populations of Clade 3 and the tri-, tetra-, and hexaploid populations that form the well supported Clade 2. The T. tubifex of Clades 2 and 3 are characterized by a high interclade genetic divergence (more than 12\%; see Table 3) suggesting the existence of a genetic barrier to gene flow [16], and should be considered distinct cryptic species. The different polyploid populations forming Clade 2 and Clade 3 may be considered polyploid forms of the same species (see, for example [20]) or distinct cryptic species. Intriguingly, the intraclade genetic divergence among $16 \mathrm{~S}$ rRNA genes ranges from $5.0 \%$ to $8.1 \%$ (see Table 2), a value comparable to the genetic divergence observed between polyploid populations of plants recognized as true polyploid species [21]. Although a formal description of these lineages falls outside the aims of this study, we stress that it was not possible to identify any consistent morphological difference between Clades 2 and 3, or between the different identified lineages [16]. The morphological characteristics traditionally used for identification in this group allowed for the identification and characterization only of T. blanchardi [17]; however, following an integrative taxonomic approach [22], the genetic complements of the various lineages (this study), their independent evolutionary histories and, perhaps, their ecological features suggested by [23], might be considered good taxonomic markers to be used for a formal description of these independent lineages.

\section{Evolution of the Tubifex species from the Lambro River}

The six euploid sets that we observed in the mixed Lambro community were coherently arranged in the mitochondrial phylogenetic tree, each lineage grouping specimens with the same chromosome complement (Figure 1). No lineages of mixed ploidy were observed, and each polyploid was represented by one or few mitochondrial haplotypes (see Table 1), as is common in parthenogenetic polyploid species [24]. Parthenogenesis may have played a key role in the evolution of polyploidy in T. tubifex and T. blanchardi, as in other clitellates $[6,25]$ and in many animal groups $[24,26]$. This pattern, together with the pattern of hybridization signals, suggests that multiple 
polyploidyzation events (perhaps associated with parthenogenesis) may have played a driving role in maintaining independently evolving species and in shaping the evolution of the Lambro T. tubifex and T. blanchardi species.

Two main hypotheses concerning chromosomal evolution are compatible with our phylogenetic analysis. In the first scenario, a diploid $(2 \mathrm{n}=50)$ common ancestor may have given rise to clades $1+2$ and 3 through two independent polyploidyzation events. Indeed, the tetraploid T. tubifex belonging to Clade 2 (lineages $2 \mathrm{~b}$ and 2d) and Clade 3 differ in their karyotypes, respectively showing none, one and four large metacentric chromosomes and different proportions of meta-, submeta- and acrocentric chromosomes (Figures 1 and 3). Following this hypothesis, T. blanchardi retained the plesiomorphic diploid state of 50 chromosomes [6]. The alternative scenario, which is more likely according to our ancestral state reconstruction analysis, suggests that the ancestor of Clades $1+2$ and 3 was instead tetraploid (Figure 1). Clade 3 may have arisen directly from this tetraploid ancestor, which probably had a similar karyotype, with four large metacentric chromosomes (Figure 1). By contrast, the diploid $T$. blanchardi (Clade 1) and the tetraploid $T$. tubifex (Clade 2; lineages 2b, 2d) evolved from a new tetraploid ancestor, characterized by a proportion of large metacentric chromosomes different from that seen in the ancestral population (Figures 1 and 3). Following this hypothesis, the diploid T. blanchardi (Clade 1) may have originated from a tetraploid secondarily, possibly by parthenogenetic development of its eggs (Figure 1). The triploid (Clade 2, lineage 2a; see Figure 1) and hexaploid T. tubifex lineages (Clade 2, lineage 2c; see Figure 1) might have originated from this tetraploid ancestor from the union of a haploid and an unreduced gamete or through hybridization among cryptic species.

Polyploid species generally have greater metabolic flexibility and are characterized by an ecological tolerance higher than that of their diploid ancestors ([27]; also see $[4,28]$ for a critical review). Although controversial, an example of environmental tolerance acquired via polyploidy concerns Artemia parthenogenetica, the polyploid populations of which are more likely to survive in polluted habitats, at suboptimal values of temperature and salinity or in the presence of elevated concentrations of cadmium, than their diploid ancestors [29]. Although several studies have demonstrated that different genetic lineages of $T$. tubifex have different habitat preferences and resistance to pollutants (see [23] and citations therein), no direct effect of ploidy on pollution resistance has been suggested. [23] showed that T. tubifex individuals belonging to different mitochondrial lineages varied consistently in cadmium resistance. Intriguingly, when the T. tubifex $16 \mathrm{~S}$ rRNA gene sequences from [23] corresponding to the lineages with different levels of cadmium resistance were mapped against our phylogeny, they grouped on the phylogenetic tree in a predictable manner. Indeed, all the sequences belonging to lineages I, II, III, IV and V sensu [23] grouped with the triploid, tetraploid and hexaploid $T$. tubifex respectively belonging to lineages $3 \mathrm{a}, 2 \mathrm{a}, 2 \mathrm{~b}, 2 \mathrm{~d}$ and $2 \mathrm{c}$ of the Lambro River, excluding sequence D6-U9 (which officially belongs to lineage II; GenBank accession number AJ225905; Additional file 1: Figure S1). The cadmium-resistant lineages (I and III) corresponded to tetraploid lineages $3 \mathrm{a}$ and $2 \mathrm{~b}$, and the less cadmiumresistant of the two (lineage II) corresponded to the triploid T. tubifex lineage 2a (Additional file 1: Figure S1). The differences in ploidy in T. tubifex may thus help to explain the differences in ecological tolerance, although this analysis must be investigated further. Similarly, the strong connection between mitochondrial lineages and ploidy levels can be extended to Tubifex specimens from other regions worldwide.

\section{Conclusions}

In this study, we propose alternative hypotheses for the evolution of the independent sympatric T. tubifex and $T$. blanchardi lineages, analyzing the chromosome-number distribution and karyotypes in relation to their phylogenetic relationships. Combining molecular phylogenetics and cytogenetics, we have found evidence for the existence of six different euploid chromosome sets coherently arranged in the Tubifex mitochondrial phylogeny, each lineage grouping specimens that share the same chromosome complement. Our results, including a FISH assay, suggest that our population comprise diploid, triploid, tetraploid and hexaploid sympatric individuals, and that the process of polyploidization, possibly enhanced by parthenogenesis, may have played an important role in both speciation and in the evolution of T. tubifex genetic lineages characterized by different resistance to pollutants. In the future, controlled breeding experiments should be performed with the different T. tubifex lineages to observe parthenogenesis and thus shed light on the reproductive strategies adopted by the different Tubifex lineages. Moreover, a phylogeny based on independent nuclear markers should allow us to understand if parthenogenesis and polyploidy are associated to interspecific hybridization.

\section{Methods}

\section{Sampling and laboratory cultures}

Specimens of T. tubifex and T. blanchardi were collected from a mixed naidid community in the Lambro River (Milano, Lombardy, Italy) between January 2006 and January 2009. Sexually mature individuals were identified under a light microscope according to the traditional taxonomic keys [30]. The worms were reared at low densities 
on a sterilized sand substrate covered with tap water, fed leaves of spinach, and kept at $20^{\circ} \mathrm{C}$. Food and water were changed weekly. So that cytogenetic and molecular analyses could be performed in parallel, 70 cocoons of $T$. tubifex and 10 cocoons of T. blanchardi were collected from the reared worms and dissected. For each cocoon, about half of the embryos were used for molecular analyses and the remaining embryos were processed for cytogenetic analysis. All specimens came from the shallow lateral trickles of the Lambro River, with the exception of 7 individuals from Estonia (kindly provided by Tarmo Timm) that were used as a reference (see Table 1). The $T$. tubifex and T. blanchardi community in the Lambro River has been analyzed previously by [16] and populations of the lateral trickles at different areas and depths of the sampling sites where molecularly and morphologically uniform, also across seasons.

\section{Molecular analysis \\ DNA extraction and sequencing}

DNA from one to three embryos for each cocoon was extracted, and the mitochondrial $16 \mathrm{~S}$ rRNA gene was sequenced. Total genomic DNA was extracted from the tissue samples using proteinase- $\mathrm{K}$ digestion $(10 \mathrm{mg} / \mathrm{ml}$ concentration), followed by a standard salt extraction. For primers and cycling protocols, see [16]. PCR products were loaded onto $1 \%$ agarose gels, stained with ethidium bromide, and visualized on a "Gel Doc" system (PeqLab). Bands of the correct size were purified using QIAquick spin columns (Qiagen) and sequenced on an automated sequencer, ABI 3130XL (Applied Biosystems, Perkin Elmer).

\section{Sequence alignment and molecular identification}

Sequences were confirmed by a BLAST search in GenBank, and chromatographs were checked by eye and edited, when necessary, using CodonCode (version 3.7.1; Codon Code Corporation). The alignment of all sequences required the inclusion of gaps to account for indels in some hypervariable regions. All newly determined sequences were submitted to GenBank (accession numbers: JQ247437-JQ247511; for details, see Table 1). All sequences obtained in this study were merged with all known haplotype sequences of $T$. blanchardi and $T$. tubifex from the Lambro River [16]. The number of base substitutions and the empirical frequencies of different nucleotides were determined using MEGA, version 5.05 [31]. Sequences were merged into haplotypes using the online application DNAcollapser v.1.0 (http://www.birc. au.dk), resulting in 16 haplotype sequences.

\section{Phylogenetic analyses}

As phylogenetic analyses based on a single marker did not provide a robust phylogenetic hypothesis for the evolution of this species complex (see Figure 1 in [16]), and as no additional embryonic DNA was available, we molecularly characterized the mitochondrial $16 \mathrm{~S}$ rRNA and COI gene fragments from additional 106 specimens of T. tubifex and T. blanchardi, 2 Limnodrilus hoffmeisteri and 2 Potamotrix bavaricus specimens [Genbank accession numbers EU117465-EU117509; EU117546-EU117547; EU311221EU311273; EU311275-EU311285 (16S); EU311286EU311382; EU311384-EU311398 (COI)], some of which were already available from [16]. The protocol described above was followed for DNA extraction and PCR amplification of the $16 \mathrm{~S}$ rRNA gene fragment. We used the primers LCO1490 5'-GGT CAA CAA ATC ATA AAG ATA TTG G-3' and HCO2198 5'-TAA ACT TCA GGG TGA CCA 9 AAA AA T CA-3' [32] to amplify an approximately 650 -bp fragment of the mitochondrial COI gene. PCRs were performed in $23 \mu \mathrm{l}$ reactions using $1.5 \mu \mathrm{l}$ of genomic DNA, $2 \mu \mathrm{l}$ of each $10 \mathrm{pmol}$ primer, $0.5 \mu \mathrm{l}$ of total dNTPs (10 mmol in water; Promega), $0.1 \mu \mathrm{l}$ of $5 \mathrm{U} /$ $\mu \mathrm{l}$ GoTaq $^{\oplus}, 5 \mu \mathrm{l} 5 \times$ Green GoTaq $^{\circ}$ Reaction Buffer (Promega) and $11.9 \mu \mathrm{l}$ of water. The PCR conditions were as follows: an initial denaturation step at $94^{\circ} \mathrm{C}$ for 90 seconds, 35 cycles of denaturation at $94^{\circ} \mathrm{C}$ for 30 seconds, annealing at $49^{\circ} \mathrm{C}$ for 45 seconds, and extension at $72^{\circ} \mathrm{C}$ for 90 seconds, with a final extension for $10 \mathrm{~min}$ at $72^{\circ} \mathrm{C}$. PCR products were loaded onto $1 \%$ agarose gels, stained with ethidium bromide, and visualized on a "Gel Doc" system (PeqLab). Bands of the correct size were purified using QIAquick spin columns (Qiagen) and sequenced on an automated sequencer ABI 3130XL (Applied Biosystems, Perkin Elmer). Identity of the sequences was confirmed with a BLAST search in GenBank. Chromatographs were checked by eye and edited, when necessary, using CodonCode (version 3.7.1; Codon Code Corporation). The alignment of all sequences required the inclusion of gaps to account for indels in some hypervariable regions of the $16 \mathrm{~S}$ rRNA gene fragment. The sequencing of these 110 samples enabled the identification of the same 16 T. tubifex and T. blanchardi haplotypes. These sequences, plus the four sequences of the outgroups L. hoffmeisteri and $P$. bavaricus, were combined with their corresponding COI sequences, and the resulting dataset was used to perform the phylogenetic analyses. The software Gblocks [33] was used to delete highly divergent regions that could not be unambiguously aligned or that were saturated by multiple substitutions. We surveyed a number of data-partitioning schemes using PartitionFinder [34]. Because the software required the user to pre-define partitions and specify them in the configuration file, we created an input configuration file that contained four partitions corresponding to individual codon positions in the COI gene fragment and the $16 \mathrm{~S}$ rRNA gene fragment, which was the most finely partitioned scheme possible in our mitochondrial dataset. We used the "greedy" algorithm (heuristic search) with 
"unlinked" branch lengths in PartitionFinder to search for the best-fit and worst-fit Schemes. A total of seven a priori schemes with varying degrees of complexity were statistically compared in PartitionFinder. We used AIC, natively implemented in PartitionFinder, to compare partitioning schemes. The more complex partition strategy (four partitions) yielded the analysis with the lowest score and therefore was identified as the optimal partitioning scheme for our analyses. The SYM + G, F81, HKY + G and SYM + I + $G$ models were identified in PartitionFinder as the bestfitting models of substitution for the 1-, 2- and 3-codon positions of the COI and the $16 \mathrm{~s}$ rRNA gene respectively.

Partition Bayesian analyses were performed using MrBayes 3.2.1 [35]. We performed four runs of 10 million generations (started on random trees) and four incrementally heated Markov chains (using default heating values), sampling the Markov chains at intervals of 1,000 generations. Convergence and mixing of chains in the Bayesian phylogenetic analyses were assessed by examining output files with the AWTY (Are We There Yet) graphical exploration software [36]. This tool confirmed that the split frequencies among runs were strongly correlated and that the topological differences between trees sampled by independent runs stabilized after ca. 1.5 million generations. Stabilization and convergence of likelihood values occurred after 2 million generations; therefore, the first 2 million generations were discarded as burn in, and eight million trees were retained and summed to generate the majority-rule consensus tree. Homologous sequences of $L$. hoffmeisteri and P. bavaricus were defined as outgroup.

\section{Ancestral state reconstruction}

Likelihood unequivocal reconstruction of traits, all treated as unordered was performed using the ancestral state module implemented in MESQUITE (version 2.75; [37]). Trait evolution and ancestral states were reconstructed by mapping each single trait on the rooted topology generated from the Bayesian analyses (Figure 1). The following morphological traits were considered in the reconstruction of evolutionary pathways: (1) number of chromosomes and (2) number of large metacentric chromosomes. As the chromosome number of $P$. bavaricus is unknown, we attributed to this species the chromosome complement $(2 \mathrm{n}=50)$ of $P$. hammoniensis [6]. For the maximumlikelihood analysis of chromosomal apomorphies and ancestral state reconstruction, we used the symmetrical Markov k-state one-parameter model (MK1). The likelihoods are reported as proportional likelihoods and are represented as pie charts in Figure 1.

\section{Cytogenetic analysis}

Cocoons were collected $48 \mathrm{~h}$ after deposition and transferred to Petri dishes in CMF buffer [Calcium Magnesium Free solution], and the embryos were carefully dissected from their cocoons in a mitosis-rich developmental stage (192 to $288 \mathrm{~h}$ after fecundation). Embryos were processed for different assays as follows:

a) Chromosome preparation. More than 350 metaphase plates were prepared from 1 to 4 embryos of $T$. blanchardi and T. tubifex specimens, as described by [38]. The embryos were incubated in CMF buffer containing $0.5 \mathrm{mg} / \mathrm{ml}$ Colcemid (GIBCO) and, after a hypotonic treatment with a $\mathrm{KCl} 2 \mathrm{mM}$ solution, were fixed with freshly prepared cold 3:1 methanol: acetic acid for $1 \mathrm{~h}$. The embryos were placed on a microscope slide on a warm plate and covered with a drop of $60 \%$ acetic acid, and their cells were mechanically dispersed in the drop by tapping the tissue with the flat end of a scalpel. The preparations were stained with GIEMSA stain (10\% GIEMSA Gurr's R66) in Sörensen buffer, rinsed in distilled water, mounted with Sintex and observed under a Jenaval optical microscope.

b) In-situ hybridization. Fluorescence in situ hybridization (FISH) on metaphase chromosomes with rRNA probes has been carried out only in a few clitellate species to assess their ploidy level: the lumbricids Eisenia foetida and Octodrilus complanatus $[39,40]$ and the hirudinean Haemopis sanguisuga [41]. Although those diploid clitellate species are not closely related, all showed FISH signals on a single chromosome pair for each metaphase plate, suggesting that the ribosomal genes are probably organized in a single multigenic cluster. More than 30 metaphase plates from T. tubifex and T. blanchardi embryos were prepared as described above and processed for FISH analysis. To prepare the homologous DNA probe for FISH experiments, total genomic DNA was isolated from approximately 100 T. tubifex and T. blanchardi specimens by standard phenol/chloroform extraction. The $18 \mathrm{~S}$ rRNA gene fragments were amplified directly from genomic DNA by PCR using the primers TIMAF 5'AMCTGGTTGATCCTGCCAG-3' and TIMBR 5'- TGATCCATCTGCAGGTTCACCT-3' [42]. PCR was performed with the following cycling protocol: $95^{\circ} \mathrm{C}$ for 5 seconds, followed by 20 cycles of $95^{\circ} \mathrm{C}$ for 30 seconds, $57^{\circ} \mathrm{C}$ for 30 seconds, and $72^{\circ} \mathrm{C}$ for 90 seconds, with a final elongation step at $72^{\circ} \mathrm{C}$ for 8 minutes. Approximately $100 \mathrm{ng}$ of the $18 \mathrm{~S}$ rRNA PCR product, purified using ammonium acetate and ethanol, was labeled with digoxigenin-11-dUTP by nick translation using the DIG-Nick translation kit (Roche). Each FISH experiment was performed in parallel on T. tubifex, T. blanchardi and human metaphase chromosome preparations (as a control for hybridization efficiency). After treatment with 
RNase A (Sigma-Aldrich), the slides were incubated for 30 seconds in $0.005 \%$ pepsin in $0.01 \mathrm{~N} \mathrm{HCl}$ at room temperature, rinsed in $\mathrm{PBS}$, denatured in $70 \%$ deionized formamide in 2XSSC for 2 minutes at $75^{\circ} \mathrm{C}$, and then dehydrated in a 70\%, 90\% and 100\% ethanol series for 2 minutes each. One hundred nanograms of labeled probe was denatured for 8 minutes at $80^{\circ} \mathrm{C}$ and then placed on the slides under a coverslip. Hybridization was performed in a sealed moist chamber at $37^{\circ} \mathrm{C}$ for 12 hours. The slides were then rapidly washed in $2 \mathrm{XSSC}$ with $50 \%$ formamide at $49^{\circ}$ $\mathrm{C}$ and then $3 \times 10$ minutes in 2XSSC with 50\% formamide at $39^{\circ} \mathrm{C}, 3 \times 10$ minutes with $2 \mathrm{XSSC}$, and $2 \times 30$ minutes in $0.1 \%$ SSC at room temperature. After the post-hybridization washes, the slides were incubated at $37^{\circ} \mathrm{C}$ for 30 minutes with an antidigoxigenin rhodamine-conjugate sheep antibody $(5 \mu \mathrm{g} / \mathrm{ml})$ (Boehringer, Mannheim). The signals were amplified by a rhodamin conjugated anti-sheep antibody from mice $(10 \mu \mathrm{g} / \mathrm{ml}$; Jackson Immunoresearch). The slides were counterstained with DAPI (4, 6'- 266 diamidino-2- fenilindole) in 4XSSC and mounted in DABCO (1,4- diazabicyclo 2.2.2 octane) antifade. Hybridization signals and DAPI fluorescence were viewed using an Axioplan (Zeiss, Jena) microscope equipped with a cooled Charge-Coupled Device (CCD) camera (Digital Pixel Inc., Brighton). Digital images were pseudo-colored and merged, allowing for the simultaneous detection of hybridization signals and DAPI chromosome counterstaining. IPLab Spectrum version 3.1.1 software with the FISH-capture extension (Digital Scientific) was used to normalize and enhance the images.

\section{Availability of supporting data}

Sequence data have been submitted to Genbank: accession numbers of the Tubifex tubifex and Tubifex blanchardi embryos, JQ247437-JQ247511. The Genbank accession numbers of the $16 \mathrm{~S}$ rRNA and COI gene fragments of the 106 Tubifex tubifex and Tubifex blanchardi, 2 Limnodrilus hoffmeisteri and 2 Potamotrix bavaricus specimens are as follows: EU117465-EU117509, EU117546-EU117547, EU3 11221- EU311273, EU311275-EU311285 (16S); EU311286EU311382, EU311384-EU311398 (COI).

\section{Additional file}

Additional file 1: Figure S1. Neighbor-joining tree of the $16 \mathrm{~S}$ rRNA gene fragment sequences of the Tubifex spp. used in this study and from [23], corresponding to the lineages with different cadmium resistances. Note that sequence D6-U9, officially belonging to lineage II (GenBank accession number AJ225905), groups with the Tubifex of lineage 2b and two other haplotypes belonging to lineage III. Bootstrap support values are indicated in front of the nodes. Ch, chromosome number; $\mathrm{Cl}$, clade; Li, lineage.

\section{Competing interests}

All contributing authors declare no conflict of interest.

\section{Authors' contributions}

RM, AC, ER and MF designed the experiments and analyzed and interpreted the data. RM, CF and ER performed the cytogenetic analyses. AC performed the phylogenetic analyses and RM and AC wrote the manuscript. All authors read an approved the final manuscript.

\section{Acknowledgements}

We are indebted to Francesco Fontana for his suggestions on metaphase plate preparation at the very beginning of this work. We are grateful to Mirella Bensi for technical assistance during FISH analysis. We are grateful to Tarmo Timm for providing T. tubifex specimens from Estonia, and we are indebted to Miguel Vences, Michela Barbuto and Maurizio Casiraghi for technical support. This research was partly supported by a MURST PRIN grant "Systematics ad reproductive strategies in selected invertebrates" to MF. The work of AC at the Technical University of Braunschweig was supported by a grant (Borsa di perezionamento all'estero) of the Università degli Studi di Milano, and during the preparation of this manuscript, AC was supported by a postdoctoral grant from the Portuguese 'Fundacao para a Ciencia e a Tecnologia' (FCT) (SFRH/BPD/72908/2010) under the Programa Operacional Potencial Humano - Quadro de Referência Estratégico Nacional funds from the European Social Fund and Portuguese Ministério da Educação e Ciência. We acknowledge the project "Genomics and Evolutionary Biology" co-financed by North Portugal Regional Operational Programme 2007/2013 (ON.2 - O Novo Norte), under the National Strategic Reference Framework (NSRF), through the European Regional Development Fund (ERDF).

\section{Author details}

'Istituto Italiano di Tecnologia (IIT), via Morego 30, Genova 16163, Italy. ${ }^{2} \mathrm{CIBIO}$, Centro de Investigação em Biodiversidade e Recursos Genéticos, Campus Agrário de Vairão, R. Padre Armando Quintas, Vairão 4485-661, Portugal. ${ }^{3}$ Università degli Studi di Pavia, Dipartimento di Genetica e Microbiologia "A. Buzzati Traverso", Via Ferrata 1, 27100 Pavia, Italy. "Universitá degli Studi di Milano, Dipartimento di Bioscienze, Via Celoria 26, 20133 Milano, Italy.

Received: 14 March 2014 Accepted: 18 March 2014

Published: 2 April 2014

\section{References}

1. Hufton AL, Groth D, Vingron H, Lehrach AJ, Poustka M, Panopoulou G: Early vertebrate whole genome duplications were predated by a period of intense genome rearrangement. Genome Res 2008, 18:1582-1591.

2. Rieseberg LH, Willis JH: Plant speciation. Science 2007, 317:910-914

3. Madlung A: Polyploidy and its effect on evolutionary success: old questions revisited with new tools. Heredity 2013, 110:99-104.

4. Otto SP, Whitton J: Polyploid incidence and evolution. Annu Rev Genet 2000, 34:401-437.

5. Coyne JA, Orr HA: Speciation. Sunderland: Sinauer Associates; 2004

6. Christensen B: Animal cytogenetics. In Annelida, Volume 2. Berlin-Stuttgart: Gebrüder Borntraeger; 1980:81.

7. Gustafsson DR, David A, Price B, Erseus C: Genetic variation in the popular lab worm Lumbriculus variegatus (Annelida:Clitellata: Lumbriculidae) reveals cryptic speciation. Mol Phylogenet Evol 2009, 51:182-189.

8. Erséus C, Wetzel MJ, Gustavsson L: ICZN rules - a farewell to Tubificidae (Annelida, Clitellata). Zootaxa 2008, 1744:66-68.

9. Brinkhurst RO, Jamieson BGM: Aquatic oligochaeta of the world. Edinburgh: Oliver and Boyd; 1971

10. Vidal $D E$, Horne AJ: Inheritance of mercury tolerance in the aquatic oligochaete Tubifex tubifex. Environ Toxicol Chem 2003, 22:2130-2135.

11. Shimitzu T, Savage RM: Expression of hunchback protein in a subset of ectodermal tetoblasts of the oligochaete annelid Tubifex. Dev Genes Evol 2002, 212:520-525.

12. Holmquist C: What is Tubifex tubifex (O.F. Müller) (Oligochaeta, Tubificidae)? Zool Scr 1983, 12:187-201.

13. Baldo L, Ferraguti M: Mixed reproductive strategy in Tubifex tubifex (Oligochaeta, Tubificidae). J Exp Zool Part A 2005, 303:168-177.

14. Gavrilov C: Contributions a l'e'tude de l'autofecondation chez les oligochetes. Acta Zool 1935, 16:21-64. 
15. Paoletti A: Cohort cultures of Tubifex tubifex forms. Hydrobiologia 1989, 180:143-150.

16. Crottini A, Marotta R, Barbuto M, Casiraghi M, Ferraguti M: The world in a River? A preliminary analysis of the $16 \mathrm{~S}$ rDNA variability of Tubifex species (Clitellata: Tubificidae) from the Lambro River. Mol Phylogenet Evol 2008, 48:1189-1203.

17. Marotta R, Crottini A, Prada V, Ferraguti M: A morphological reappraisal of Tubifex blanchardi Vejdovský, 1891 (Clitellata: Tubificidae). Acta Zool 2009, 9:179-188.

18. Paoletti A, Pagani M, Leoni B: Enzymatic variability in sympatric species of Tubifex (Clitellata: Tubificidae). Hydrobiologia 1999, 406:83-86.

19. Achurra A, Arantzazu Elejalde M, Rodriguez P: Phylogenetic analysis of oligochaete Tubificinae (Annelida: Clitellata) based on mitochondrial sequence data. Invertebr Syst 2011, 25:208-218.

20. Victorov AG: Diversity of polyploid races in the family Lumbricidae. Soil Biol Biochem 1997, 29:217-221.

21. Mes THM, Wijers GJ, t Hart H: Phylogenetic relationships in Monanthes (Crassulaceae) based on morphological, chloroplast and nuclear DNA variation. J Evol Biol 1997, 10:193-216.

22. Padial JM, Miralles A, de la Riva I, Vences M: The integrative future of taxonomy. Front Zool 2010, 7:16.

23. Sturmbauer C, Opadiya GB, Niederstatter H, Riedmann A, Dallinger R: Mitochondrial DNA reveals cryptic oligochaete species differing in cadmium resistance. Mol Biol Evol 1999, 16:967-974.

24. Baxevanis AD MS, Kappas I, Deligiannidis P, Triantafyllidis A, Papakostas S, Bougiouklis D, Abatzopulos TJ: Is polyploidy a persevering accident or an adaptive evolutionary pattern? The case of the brine shrimp Artemia. Mol Phylogenet Evol 2011, 58:353-364.

25. Shen H, Tsai C, Fang Y, Chen J: Parthenogenesis, polyploidy and reproductive seasonality in the Taiwanese mountain earthworm Amynthas catenus Tsai et al., 2001 (Oligochaeta, Megascolecidae). Pedobiologia 2011, 54:133-139.

26. Jose C, Dufresne F: Differential survival among genotypes of Daphnia pulex differing in reproductive mode, ploidy level, and geographic origin. Evol Ecol 2010, 24(2):413-421.

27. Litvinchuk SN, Mazepa GO, Pasynkova RA, Sai-dov A, Satorov T, Chikin YA, Shabanov DA, Crottini A, Borkin LJ, Rosanov JM, Stöck M: Influence of environmental conditions on the distribution of Central Asian green toads with three ploidy levels. J Zool Syst Evol Res 2011, 49(3):233-239.

28. Oswald B, Nuismer SL: Neopolyploidy and diversification in Huechera grosulariifolia. Evolution 2011, 65:1667-1679.

29. Sarabia R, Del Ramo J, Varo I, Di'Az-Mayans J, Torreblanca A: Comparing the acute response to cadmium toxicity of naupli from different populations of Artemia. Environ Toxicol Chem 2002, 21:437-444

30. Timm T: A Guide to the Estonian Annelida. Tartu-Tallinn: Estonian Academy Publishers; 1999

31. Tamura K, Peterson D, Peterson N, Stecher G, Nei M, Kumar S: MEGA5: Molecular Evolutionary Genetics Analysis using Maximum Likelihood, Evolutionary Distance, and Maximum Parsimony Methods. Mol Biol Evol 2011, 28:2731-2739.

32. Folmer $\mathrm{O}$, Black M, Hoeh W, Lutz R, Vrijenhoek R: DNA primers for amplification of mitochondrial cytochrome c oxidase subunit I from diverse metazoan invertebrates. Mol Mar Biol Biotech 1994, 3:294-299.

33. Castresana J: Selection of conserved blocks from multiple alignments for their use in phylogenetic analysis. Mol Biol Evol 2000, 17:540-552.

34. Lanfear R, Calcott B, Ho S, Guindon S: PartitionFinder: Combined selection of partitioning schemes and substitution models for phylogenetic analyses. Mol Biol Evol 2012, 29:1695-1701.

35. Ronquist F, Teslenko M, van der Mark P, Ayres DL, Darling A, Höhna S, Larget B, Liu L, Suchard MA, Huelsenbeck JP: MrBayes 3.2: efficient Bayesian phylogenetic inference and model choice across a large model space. Syst Biol 2012, 61(3):539-542.

36. Nylander JAA, Wilgenbusch JC, Warren DL, Swofford DL: AWTY (are we there yet?): a system for graphical exploration of MCMC convergence in Bayesian phylogenetics. Bioinformatics 2008, 4:581-583.

37. Maddison WP, Maddison DR: Mesquite: a modular system for evolutionary analysis. ; 2011. Version 2.75 http://mesquiteproject.org.

38. Webb GC, White MJD, Contreras N, Cheney J: Cytogenetics of the parthenogenetic grasshopper Warramaba (formely Moraba) virgo and its bisexual relatives 4: Chromosome banding studies. Chromosoma 1978, 67:309-339.
39. Vitturi R, Colombera D, Catalano E, Amico FP: Karyotype analysis, nucleolus organizer regions and C-banding pattern of Eisenia foetida (Oligochaeta, Lumbricidae). Genetica 1991, 83:159-165.

40. Vitturi R, Libertini A, Armetta F, Sparacino L, Colomba MS: Physica mapping of rDNA genes, (TTAGGG)n telomeric sequence and other karyological features in two earthworms of the family Lumbricidae (Annelida: Oligochaeta). Heredity 2000, 85:203-207.

41. Vitturi R, Libertini A, Armetta F, Sparacino L, Colomba MS: Chromosome analysis and FISH mapping of ribosomal DNA (rDNA), telomeric (TTAGGG)n and (GATA)n repeats in the leech Haemopis sanguisuga (L.) (Annelida: Hirudinea). Genetica 2002, 115:189-194.

42. Erséus C, Prestegaard T, Kallersjo M: Phylogenetic analysis of Tubificidae (Annelida, Clitellata) based on 18S rDNA sequences. Mol Phylogenet Evol 2000, 15:381-389.

doi:10.1186/1471-2148-14-73

Cite this article as: Marotta et al:: Alike but different: the evolution of the Tubifex tubifex species complex (Annelida, Clitellata) through polyploidization. BMC Evolutionary Biology 2014 14:73.

\section{Submit your next manuscript to BioMed Central and take full advantage of:}

- Convenient online submission

- Thorough peer review

- No space constraints or color figure charges

- Immediate publication on acceptance

- Inclusion in PubMed, CAS, Scopus and Google Scholar

- Research which is freely available for redistribution 